・保护论坛・

\title{
中国大陆自然保护地概况及分类体系构想
}

\author{
彭杨靖 樊 简 郱韶华 崔国发* \\ (北京林业大学自然保护区学院, 北京 100083)
}

\begin{abstract}
摘要：自1956年我国建立第一个自然保护区以来, 截至2016年底, 我国已建立了约10种类型且数量庞大的自然保 护地。随着我国生态文明建设的不断发展, 建立以国家公园为主体的自然保护地体系不仅是国家提出的重要任务, 也是我国自然保护地未来发展的必然趋势。然而, 由于我国目前各类自然保护地尚无统一的分类体系, 已有的自 然保护地之间存在着概念界定不清、分类体系混乱、主导功能模糊、地理空间重叠等诸多问题。这不仅严重阻碍 了我国现有自然保护地的优化整合和国家公园体制建设, 而且不便于开展国际交流。因此迫切需要明确自然保护 地的定义, 建立一套适用于我国且有利于国际交流的自然保护地分类体系。本文在介绍自然保护地的概念与内涵, 以及我国10类自然保护地建设和分类体系现状的基础上, 重点梳理了我国自然保护地的发展历程, 比较了各类自 然保护地的定义、内涵以及主要分类依据, 并提出了 3 种能够涵盖目前各类自然保护地的分类体系构想, 它们分 别基于IUCN保护区分类系统、保护对象自然属性和管理目标社会属性。希望这些构想能在未来自然保护地分类 体系的研究中起到抛砖引玉的作用。
\end{abstract}

关键词：自然保护地; 分类体系; 国家公园体制; 整合

\section{Overview and classification outlook of natural protected areas in mainland China}

Yangjing Peng, Jian Fan, Shaohua Xing, Guofa Cui *

School of Nature Conservation, Beijing Forestry University, Beijing 100083

\begin{abstract}
By the end of 2016, China had established approximately 10 types and a large number of natural protected areas since the first nature reserve was established in 1956. With ecological civilization construction, to establish a natural protected areas system based on national parks is not only an important project put forward by the state, but also the inevitable trend for future development. However, problems including ambiguous concepts, confused classification systems, vague dominant functions, and geospatial overlap also accompanied these natural protected areas. There is still no unified classification system that can be applied in all types of natural protected areas in China, this lack of classification system has seriously impeded ongoing optimization and integration of the existing natural protected areas and the construction of a national park system and is not convenient for international academic exchanges. Therefore, defining natural protected areas is urgently needed and is essential for the establishment of a classification system that is applicable to our country and conducive to international communication. Here we mainly discuss the concepts and connotation of natural protected areas in China, tease out their development processes, and summarize the construction and classification of 10 types of natural protected areas, while comparing the similarities and differences of these concepts and classifications. Finally, based on the IUCN protected area management classification system, the natural attribution of protected objects, and social attribution of management objects, we propose three classification systems to provide a reference for establishing a natural protected area classification system and national park system. We hope these systems will play a role in the study of the classification system of natural protected areas in the future.
\end{abstract}

Key words: protected area; classification system; national park system; integration

收稿日期: 2017-09-01; 接受日期: 2018-01-26

基金项目: 中央高校基本科研业务费专项资金(2015ZCQ-BH-02)

* 通讯作者 Author for correspondence. E-mail: fa6716@163.com 
1994年世界自然保护联盟(International Union for Conservation of Nature, IUCN)下设的世界保护 区委员会(World Commission on Protected Areas, WCPA)发布了《保护区管理类型指南》(Guidelines for Protected Area Management Categories), 根据管 理目标把种类繁多的保护区划分为6类，即IUCN保 护区分类系统(IUCN Protected Areas Categories System)。该保护区分类系统获得联合国、《生物多 样性公约》和许多国家政府的认可, 成为定义和记 录保护区的国际标准，也被越来越多地纳入政府的 立法中(Dudley, 2008)。

我国目前暂无统一的保护区分类体系, 且各类 自然保护地种类多、数量大, 有的处于建设试点的 阶段, 如国家沙漠公园试点等(http://www.gov.cn/ xinwen/2016-10/12/5117747/files/0c2894b0be794f86829bbd65d7809bee.pdf); 有的经过多年的摸索, 已 经形成了较为成熟的体系, 例如自然保护区、风景 名胜区、森林公园、地质公园等。而这些自然保护 地自成体系, 存在着空间布局重叠、主导功能模糊 等诸多问题。本文从各类自然保护地的定义、功能、 分类情况以及当前的建设现状进行对比，以期为我 国各类自然保护地的整合及建立国家公园体制提 供参考。

\section{自然保护地的概念与内涵}

根据我国现行的《自然保护区名词术语》 (GB/T 31759-2015) (中华人民共和国国家质量监督 检验检疫总局和中国国家标准化管理委员会, 2015) 中对保护区(Protected Area)的定义，保护区是用于 生物多样性、自然及文化资源保护, 并通过法律和 其他有效手段进行管理的特定区域。2008年IUCN 制定的保护区分类系统中对保护区(Protected Area) 的定义是: 一个边界明晰的地理空间, 通过法律或 其他有效手段获得认可、承诺并被专门管理, 以实 现长期的自然保护及相关的生态系统服务和文化 价值保护(Dudley, 2008)。两种定义都明确了保护区 的确立和管理方式是通过法律或其他有效手段，目 的是自然和文化保护。不同点仅在于二者对保护区 范围的表述：IUCN的定义明确了保护区的范围是 “边界明晰的地理空间”, 《自然保护区名词术语》

(GB/T 31759-2015)中的表述是“特定区域”。

整个保护区体系包括了以自然特征为主和以
人文特征为主的保护区两大类，这两大类保护区的 保护对象、建立方式和管理目标等存在较大差别。 前者包括自然保护区、湿地公园、森林公园等，后 者包括各种历史文化保护区、文化遗产地、历史遗 迹等。本文主要讨论以自然特征为主的保护区。

由于目前对于自然特征为主的保护区并无标 准的定义，本文根据《建立国家公园体制总体方案》 (http://www.gov.cn/zhengce/2017-09/26/content_5227 713.htm)中的表述，将各类以自然特征为主的保护 区统一称为自然保护地。通过统计，目前我国大陆 的自然保护地主要包括10类，按始建时间顺序分别 为：自然保护区、风景名胜区(自然景观类)、森林 公园、地质公园、水利风景区(包括水库型、湿地型、 自然河湖型)、湿地公园、海洋特别保护区、水产种 质资源保护区、国家公园和沙漠公园。

\section{2 自然保护地类型的发展历程}

按照各类型自然保护地的出现顺序及其功能, 可以将其发展历程分为 4 个阶段(图1):

第一是单一自然保护阶段(1956-1981年)。1956 年，我国的第一个自然保护区广东鼎湖山自然保护 区建立，标志着我国自然保护地发展的起点(王献 溥和崔国发，2003)，其后的25年内没有出现其他类 型的自然保护地。该阶段中，自然保护区只有单一 的自然保护功能。

第二是游憩功能兴起阶段(1982-1999年)。1982 年，风景名胜区作为我国第二个类型的自然保护地 出现; 同年, 森林公园开始建立。该阶段共17年, 这

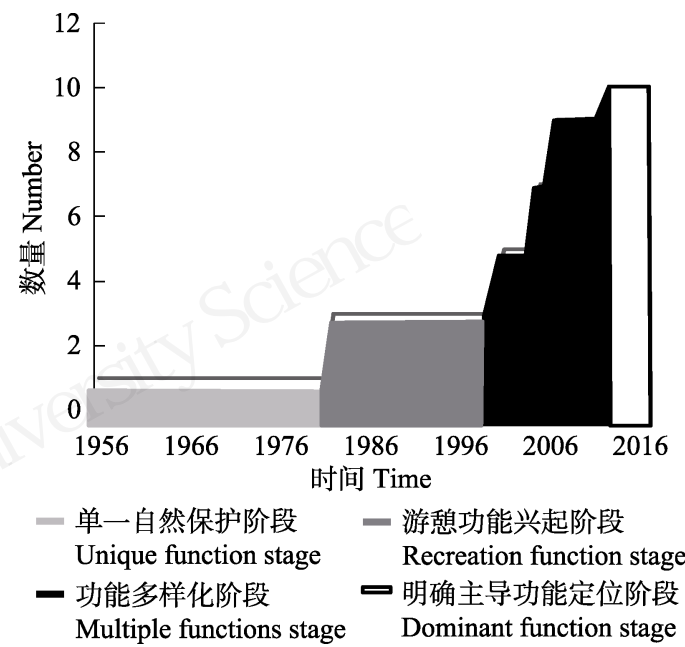

图1 自然保护地类型数量随时间变化的 4 个阶段

Fig. 1 The types of natural protected area over time 
表1 我国大陆自然保护地的数量及面积统计(数据截至2016年底)

Table 1 The number and area of natural protected area (until the end of 2016)

\begin{tabular}{|c|c|c|c|c|c|c|c|c|c|c|c|}
\hline \multirow[t]{2}{*}{ 类型 Type } & \multicolumn{2}{|c|}{ 国家级 National-level } & \multirow[b]{2}{*}{$\begin{array}{l}\text { 省级 } \mathrm{I} \\
\text { 数量 } \\
\text { Num- } \\
\text { ber }\end{array}$} & \multirow{2}{*}{$\begin{array}{l}\text { Province-level } \\
\text { 面积(万公 } \\
\text { 顷) } \\
\text { Area }\left(\times 10^{4}\right. \\
\text { ha) }\end{array}$} & \multirow{2}{*}{$\begin{array}{l}\text { 市级 } \\
\text { 数量 } \\
\text { Num- } \\
\text { ber }\end{array}$} & \multirow{2}{*}{$\begin{array}{l}\text { City-level } \\
\text { 面积(万公 } \\
\text { 顷) } \\
\text { Area }\left(\times 10^{4}\right. \\
\text { ha) }\end{array}$} & \multicolumn{2}{|c|}{ 县级 County-level } & \multicolumn{2}{|c|}{ 总数 Total } & \multirow[b]{2}{*}{$\begin{array}{l}\text { 主管部门 } \\
\text { Affiliation }\end{array}$} \\
\hline & $\begin{array}{l}\text { 数量 } \\
\text { Number }\end{array}$ & $\begin{array}{l}\text { 面积(万公 } \\
\text { 顷) } \\
\text { Area }\left(\times 10^{4} \mathrm{ha}\right)\end{array}$ & & & & & $\begin{array}{l}\text { 数量 } \\
\text { Number }\end{array}$ & $\begin{array}{l}\text { 面积(万公 } \\
\text { 顷) } \\
\text { Area }\left(\times 10^{4}\right. \\
\text { ha) }\end{array}$ & $\begin{array}{l}\text { 数量 } \\
\text { Number }\end{array}$ & $\begin{array}{l}\text { 面积 (万公 } \\
\text { 顷) } \\
\text { Area }\left(\times 10^{4}\right. \\
\text { ha) }\end{array}$ & \\
\hline $\begin{array}{l}\text { 自然保护区 } \\
\text { Nature reserve }\end{array}$ & 446 & 9,695 & 871 & 3,767 & 403 & 445 & 1,030 & 826 & 2,750 & 14,733 & $\begin{array}{l}\text { 多部门管理 } \\
\text { Multiple } \\
\text { authorities }\end{array}$ \\
\hline $\begin{array}{l}\text { 风景名胜区 } \\
\text { Scenic and } \\
\text { historical area }\end{array}$ & 225 & 10.36 & 737 & 9.2 & - & - & - & - & 1,025 & 19.56 & $\begin{array}{l}\text { 住房和城乡 } \\
\text { 建设部 } \\
\text { MOHURD }\end{array}$ \\
\hline $\begin{array}{l}\text { 森林公园 } \\
\text { Forest park }\end{array}$ & 827 & $1,251.06$ & 1,402 & 417.99 & - & - & 1,005 & 132.66 & 3,234 & $1,801.71$ & $\begin{array}{l}\text { 国家林业局 } \\
\text { SFA }\end{array}$ \\
\hline $\begin{array}{l}\text { 湿地公园 } \\
\text { Wetland park }\end{array}$ & $\begin{array}{l}\text { 正式 Official } \\
98 \\
\text { 试点 Pilot } \\
607\end{array}$ & 36 & 274 & 283 & - & - & - & - & 979 & 319 & $\begin{array}{l}\text { 国家林业局 } \\
\text { SFA }\end{array}$ \\
\hline $\begin{array}{l}\text { 沙漠公园(试点) } \\
\text { Pilot desert park }\end{array}$ & 55 & 29.73 & - & - & - & - & - & - & 55 & 29.73 & $\begin{array}{l}\text { 国家林业局 } \\
\text { SFA }\end{array}$ \\
\hline $\begin{array}{l}\text { 地质公园 } \\
\text { Geopark }\end{array}$ & $\begin{array}{l}\text { 批准建立189 } \\
\text { 处, 已授予资 } \\
\text { 格52处 } \\
189 \text { were } \\
\text { approved and } \\
52 \text { got the } \\
\text { qualification }\end{array}$ & 1,199 & 235 & $\begin{array}{l}\text { 缺少数据 } \\
\text { Lack of data }\end{array}$ & - & - & 0 & 0 & 424 & $1,199+$ & $\begin{array}{l}\text { 国土资源部 } \\
\text { MOLR }\end{array}$ \\
\hline $\begin{array}{l}\text { 海洋特别保护区 } \\
\text { Special marine } \\
\text { reserve }\end{array}$ & 59 & 696 & 0 & 0 & - & - & - & - & 59 & 696 & $\begin{array}{l}\text { 国家海洋局 } \\
\text { SOA }\end{array}$ \\
\hline $\begin{array}{l}\text { 水利风景区 } \\
\text { Water park }\end{array}$ & 719 & $\begin{array}{l}\text { 缺少数据 } \\
\text { Lack of data }\end{array}$ & 1,781 & $\begin{array}{l}\text { 缺少数据 } \\
\text { Lack of data }\end{array}$ & - & - & - & - & 2,500 & $\begin{array}{l}\text { 缺少数据 } \\
\text { Lack of } \\
\text { data }\end{array}$ & $\begin{array}{l}\text { 水利部 } \\
\text { MOWR }\end{array}$ \\
\hline $\begin{array}{l}\text { 水产种质资源 } \\
\text { 保护区 } \\
\text { Fishery genetic } \\
\text { resources reserve }\end{array}$ & 523 & $1,330.92$ & $\begin{array}{l}\text { 缺少 } \\
\text { 数据 } \\
\text { Lack of } \\
\text { data }\end{array}$ & $\begin{array}{l}\text { 缺少数据 } \\
\text { Lack of data } \\
\text { ff }\end{array}$ & - & - & - & - & $523+$ & $1,330.92$ & $\begin{array}{l}\text { 农业部 } \\
\text { MOA }\end{array}$ \\
\hline $\begin{array}{l}\text { 国家公园体制试点 } \\
\text { Pilot national park }\end{array}$ & & $1,685.49$ & 10 & 3,059 & - & - & - & - & 19 & $4,744.49$ & $\begin{array}{l}\text { 发改委牵头 } \\
\text { NDRC }\end{array}$ \\
\hline $\begin{array}{l}\text { 总计 } \\
\text { Total }\end{array}$ & 3,753 & $\begin{array}{l}15,933.56+ \\
\text { (未除去重叠 } \\
\text { 区域) } \\
\text { (Did not } \\
\text { remove the } \\
\text { overlap) }\end{array}$ & $5,310+$ & $\begin{array}{l}\text { 7,536.19 } \\
\text { (未除去重 } \\
\text { 叠区域) } \\
\text { (Did not } \\
\text { remove the } \\
\text { overlap) }\end{array}$ & 403 & 445 & 2,035 & $\begin{array}{l}958.66 \\
\text { (未除去重 } \\
\text { 叠区域) } \\
\text { (Did not } \\
\text { remove the } \\
\text { overlap) }\end{array}$ & $11,568+$ & $\begin{array}{l}24,873.41 \\
\text { (未除去重 } \\
\text { 叠区域) } \\
\text { (Did not } \\
\text { remove the } \\
\text { overlap) }\end{array}$ & \\
\hline
\end{tabular}

MOHURD, Ministry of Housing and Urban-Rural Development of the People's Republic of China; SFA, The State Forestry Administration of the People's Republic of China; MOLR, Ministry of Land and Resources of the People's Republic of China; SOA, State Oceanic Administration of the People's Republic of China; MOWR, The Ministry of Water Resources of the People's Republic of China; MOA, Ministry of Agriculture of the People's Republic of China; NDRC, National Development and Reform Commission.

两种类型的自然保护地为人们提供了游息观光及 森林旅游的功能(李柏青等, 2009; 贾建中, 2012)。

第三是功能多样化阶段(2000-2014年)。该阶段 的14年间，相继出现了7种类型的自然保护地，不 论是类型还是数量都呈井喷式增长, 其功能也呈现 多样化。按照其建立的时间顺序分别为: 地质公园
(2000年)、水利风景区(2001年)、湿地公园(2005年)、 海洋特别保护区(2005年)、水产种质资源保护区 (2007年)、国家公园(2007年)、沙漠公园(2013年)(后 立胜, 2005; 刘东朴等, 2010; 余凤龙等, 2012; 杨永 峰, 2014)。云南省挂牌成立的云南省迪庆藏族自治 州香格里拉普达措国家公园，是大陆首个以“国家 
公园”命名的自然保护地, 而在国家层面上开始建 设国家公园体制试点的时间为2015年。

第四是明确主导功能定位阶段(2015年至今)。 2013年11月 《中共中央关于全面深化改革若干重大 问题的决定》文件中第一次提到“建立国家公园体 制”，我国大陆开始在国家公园体制上有所举措， 旨在对自然保护地进行梳理, 建立完整的主导功能 体系(杨锐, 2016)。嗔 2015年1月20日，国家发改委 等13个部门联合下发《建立国家公园体制试点方 案》, 确定了北京、吉林、黑龙江、浙江、福建、 湖北、湖南、云南和青海共 9 个国家公园体制试点 省(市), 要求每个试点省(市)选取 1 个区域开展试 点。该阶段中, 我国开始思考和实践如何整合优化 自然保护地, 解决其主导功能模糊、交叉重叠和管 理混乱等问题。目前批建的国家公园体制试点有 10
个, 分别为: 北京长城、东北虎豹、大熊猫、浙江 钱江源、湖南南山、福建武夷山、湖北神农架、云 南普达措、青海三江源和祁连山。

\section{各类型自然保护地的现状对比}

\section{1 各类型自然保护地的定义}

分别整理我国各类自然保护地的定义(Box 1) 发现，尽管各类自然保护地的名称不同，但在以下 几方面有共同之处: (1)地理空间属性: 都需要划定 一定地理区域; (2)自然属性：都以自然景观、自然 生态系统、野生动植物及有关附属系统为载体或介 质; (3)功能属性: 都具有游媳、休闲功能, 都可以开 展科学、文化、宣传和教育活动; (4)确立方式: 都 有法规、条例或者管理办法等有关行政法规，或者 政府机关审批确定。

\section{Box 1 我国各类型自然保护地的定义对比}

\section{自然保护区}

定义: 对有代表性的自然生态系统、珍稀濒危野生动植物物种的天然集中分布区、有特殊意义的自然遗迹等保护对象 所在的陆地、陆地水体或者海域，依法划出一定面积予以特殊保护和管理的区域。

定义来源：《中华人民共和国自然保护区条例》(2017年修订)。

地理空间属性: 一定面积的区域: 陆地、陆地水体或者海域。

自然属性: 有代表性的自然生态系统、珍稀濒危野生动植物物种的天然集中分布区、有特殊意义的自然遗迹等。

功能属性: 予以特殊保护和管理。

确立方式: 设立国家级自然保护区由国务院环境保护行政主管部门提出审批建议，报国务院批准; 设立地方级自然 保护区由省、自治区、直辖市人民政府环境保护行政主管部门提出审批建议，报省、自治区、直辖市人民政府批准。

\section{风景名胜区}

定义: 具有观赏、文化或者科学价值, 自然景观、人文景观比较集中，环境优美，可供人们游览或者进行科学、文化 活动的区域。

定义来源：《风景名胜区条例》(2006年)。

地理空间属性: 区域。

自然属性: 自然景观。

功能属性: 可供人们游览或者进行科学、文化活动。

确立方式: 设立国家级风景名胜区由省、自治区、直辖市人民政府提出申请，报国务院批准公布; 设立省级风景名胜 区由县级人民政府提出申请，报省、自治区、直辖市人民政府批准公布。

\section{森林公园}

定义: 森林景观优美，自然景观和人文景物集中，具有一定规模，可供人们游览、休息或进行科学、文化、教育活动 的场所。

定义来源：《森林公园管理办法》(2016年修订)。

地理空间属性: 场所。

自然属性：森林景观优美，自然景观和人文景物集中，具有一定规模。

功能属性: 可供人们游览、休息或进行科学、文化、教育活动。

确立方式: 设立国家级森林公园由省级林业主管部门提出申请，报国家林业局审批; 设立省级森林公园和市、县级森 林公园由相应的省级或者市、县级林业主管部门审批。 


\section{湿地公园}

定义: 以保护湿地生态系统、合理利用湿地资源、开展湿地宣传教育和科学研究为目的, 经国家林业局批准设立, 按 照有关规定予以保护和管理的特定区域。

定义来源：《国家湿地公园管理办法》(2018年)。

地理空间属性: 特定区域

自然属性: 湿地生态系统、湿地资源。

功能属性: 可供开展湿地保护、恢复、宣传、教育、科研、监测、生态旅游等活动。

确立方式: 设立国家湿地公园由省级林业主管部门向国家林业局提出申请，国家林业局批准建立。

\section{沙漠公园}

定义：以沙漠景观为主体，以保护荒漠生态系统为目的，在促进防沙治沙和保护生态功能的基础上，合理利用沙区资 源，开展公众游息、旅游休闲和进行科学、文化、宣传和教育活动的特定区域。

定义来源：《国家沙漠公园试点建设管理办法》(2014年)。

地理空间属性: 特定区域。

自然属性: 沙漠景观。

功能属性: 保护荒漠生态系统为目的; 开展公众游憩、旅游休闲和进行科学、文化、宣传和教育活动。

确立方式: 设立国家沙漠公园由省级林业行政主管部门将拟进行国家沙漠公园试点建设的相关材料报国家林业局。建 设国家沙漠公园须经当地县级以上(含县级)人民政府确认。

\section{地质公园}

定义: 对具有国际、国内和区域性典型意义的地质遗迹，可建立国家级、省级、县级地质遗迹保护段、地质遗迹保护 点或地质公园。

定义来源：《地质遗迹保护管理规定》(1995年)。

地理空间属性: 特定区域。

自然属性: 地质遗迹景观为主体, 融合其他自然景观。

功能属性: 具有典型的地质科学意义、稀有的自然属性、重要的美学观赏价值。

确立方式: 设立国家级地质遗迹保护区由国务院批准、公布; 省级地质遗迹保护区的建立由省、自治区、直辖市人民 政府批准、公布; 县级地质遗迹保护区的建立由县(市)级人民政府批准、公布。

\section{海洋特别保护区(包括海洋公园)}

定义: 具有特殊地理条件、生态系统、生物与非生物资源及海洋开发利用特殊要求，需要采取有效的保护措施和科学 的开发方式进行特殊管理的区域。

定义来源：《海洋特别保护区管理办法》(2010年)。

地理空间属性: 进行特殊管理的区域。

自然属性: 生态系统、生物与非生物资源。

功能属性: 需要采取有效的保护措施和科学的开发方式。

确立方式: 设立国家级海洋特别保护区，由沿海省、自治区、直辖市人民政府海洋行政主管部门提出申请，经沿海同 级人民政府同意后，报国家海洋局批准设立; 设立地方级海洋特别保护区，由沿海县级以上人民政府海洋行政主管部门提 出申请, 报沿海同级人民政府批准设立。

\section{水利风景区}

定义: 以水域(水体)或水利工程为依托, 具有一定规模和质量的风景资源与环境条件, 可以开展观光、娱乐、休闲、 度假或科学、文化、教育活动的区域。

定义来源: 《水利风景区管理办法》(2004年)。

地理空间属性: 区域。

自然属性: 水域(水体)。

功能属性: 可以开展观光、娱乐、休闲、度假或科学、文化、教育活动。

确立方式: 设立国家级水利风景区由景区所在市、县人民政府提出申请，由水利部公布; 省级水利风景区由景区所在 地市、县人民政府提出，报省、自治区、直辖市水行政主管部门评定公布。 


\section{水产种质资源保护区}

定义: 为保护水产种质资源及其生存环境, 在具有较高经济价值和遗传育种价值的水产种质资源的主要生长繁育区 域, 依法划定并予以特殊保护和管理的水域、滩涂及其毗邻的岛礁、陆域。

定义来源：《水产种质资源保护区管理暂行办法》(2011年)。

地理空间属性: 进行特殊管理的水域、滩涂及其毗邻的岛礁、陆域。

自然属性：具有较高经济价值和遗传育种价值的水产种质资源的主要生长繁育区域。

功能属性: 保护水产种质资源及其生存环境。

确立方式: 农业部和省级人民政府渔业行政主管部门分别设立国家级和省级水产种质资源保护区评审委员会，对申 报的水产种质资源保护区进行评审。

\section{国家公园(体制试点)}

定义: 由国家批准设立并主导管理，边界清晰，以保护具有国家代表性的大面积自然生态系统为主要目的，实现自然 资源科学保护和合理利用的特定陆地或海洋区域。

定义来源：《建立国家公园体制总体方案》(2017年)。

地理空间属性: 特定陆地或海洋区域。

自然属性: 具有国家代表性的大面积自然生态系统。

功能属性: 实现自然资源科学保护和合理利用。

确立方式: 由国家批准设立并主导管理。

需要说明的是, IUCN保护区分类系统中对国 家公园的定义是“大面积的自然或近自然的区域, 设立的目的是为了保护大尺度的生态过程及相关 的物种和生态系统, 同时提供环境和文化相容的精 神享受、科研、教育、游唕和参观机会的条件”。

我国暂时还没有法律、法规上的“国家公园”概 念。《自然保护区名词术语》(GB/T31759-2015)给出 的定义为: “国家公园 (national park)为保护具有国 家或国际重要意义的自然区域而划定的陆地或海 域。其管理目标是在保护自然生态系统、物种及其 生境或自然遗迹的同时为人类提供娱乐和游秝的场 所”。《国家公园基本条件》(DB53/T 298-2009) (云 南省质量技术监督局, 2009)中的定义是: “由政府 划定和管理的保护地, 以保护具有国家或国际重要 意义的, 兼有科研、教育、游悡和社区发展等功能, 是实现资源有效保护和合理利用的特定区域。”

2017年9月中共中央办公厅、国务院办公厅印 发的《建立国家公园体制总体方案》中对“国家公 园”作出了定义，即“国家公园是指由国家批准设立 并主导管理, 边界清晰, 以保护具有国家代表性的 大面积自然生态系统为主要目的, 实现自然资源科 学保护和合理利用的特定陆地或海洋区域”。中国 特色的国家公园建设的主要目的是保护大面积自 然生态系统; 其首要功能是重要自然生态系统的原
真性、完整性保护，同时兼具科研、教育、游悡等 综合功能。

\section{2 各类型自然保护地分类现状的对比}

(1)自然保护区。我国自然保护区按照其主要保 护对象来划分, 一共分为 3 个类别、 9 个类型。自然 生态系统类包括森林、草原与草甸、荒漠、内陆湿 地和水域、海洋和海岸带生态系统5个类型; 野生生 物类包括野生动物和野生植物 2 个类型; 自然遗迹 类包括地质遗迹和古生物遗迹 2 个类型，见《自然保 护区类型与级别划分原则》(GB/T 14529-93)。在学 术研究中, 蒋明康等(2004)基于IUCN保护区分类系 统将中国自然保护区分为严格自然保护区、荒野地 自然保护区、国家公园、自然遗迹自然保护区、野 生生物物种自然保护区、自然生态系统自然保护区 和资源管理自然保护区6个类型。

(2)风景名胜区。按照其主要特征可分为14类, 分别为历史圣地类、山岳类、岩洞类、江河类、湖 泊类、海滨海岛类、特殊地貌类、城市风景类、生 物景观类、壁画石窟类、纪念地类、陵寝类、名俗 风情类和其他类, 见《风景名胜区分类标准》 $(\mathrm{CJJ} / \mathrm{T}$ 121-2008)。其中历史圣地类、城市风景类、壁画石 窟类、纪念地类、陵寝类、民俗风情类以人文景观 为主; 山岳类、岩洞类、江河类、湖泊类、海滨海 岛类、特殊地貌类、生物景观类以自然景观为主。 
其中自然景观类别的风景名胜区属于本文所探讨 的自然保护地范畴内。另外, 李晓黎和韩锋(2015) 按照风景名胜区的级别、规模、景观外貌、结构特 征、布局形式和功能特征对其分类方法进行了总 结, 按管理级别分为国家级和省级风景名胜区; 按 规模分为小型、中型、大型和超大型风景名胜区; 按 结构特征分为单一型、复合型和综合型风景名胜区; 按功能设施分为观光型、游㮩型、休假型、民俗型、 生态型、综合型风景名胜区等。

(3)森林公园。国家正式的法律法规、部门规章 中暂无通用的分类规定。学术研究中陈戈等(2001) 将森林公园按照地貌景观分为 10 个类型, 分别为山 岳型、江湖型、海岸/岛屿型、沙漠型、火山型、冰 川型、洞穴型、草原型、瀑布型和温泉型。

(4)湿地公园。国家正式的法律法规、部门规章 中暂无通用的分类规定。在学术研究中, 赵思毅和 侍菲菲(2006)根据其内涵和形成过程, 将湿地公园 分为自然湿地公园和人工湿地公园两大类，其中自 然湿地公园又可划分为滨海湿地公园、河流湿地公 园和湖沼湿地公园。根据国家级湿地公园批准部门 的不同，可将湿地公园分为国家湿地公园和国家城 市湿地公园, 前者由原国家林业局批准建设, 后者 由住房和城乡建设部批准建设。

(5)沙漠公园。国家正式的法律法规、部门规章 中暂无通用的分类规定, 也暂无关于沙漠公园类型 划分的相关研究。

(6)地质公园。国家正式的法律法规、部门规章 中暂无通用的分类规定。在学术研究中, 吴胜明 (2003)根据地质地貌将地质公园分为 13 类, 分别为 丹霞地貌、火山地质地貌、古生物化石、地质剖面、 峡谷地貌、岩溶地貌、冰川地貌、地质灾害遗迹、 砂岩峰林地貌、构造地质、风蚀地貌、花岗岩地貌 和瀑布类型。

(7)海洋特别保护区。根据海洋特别保护区的地 理区位、资源环境状况、海洋开发利用现状和社会 经济发展的需要, 海洋特别保护区可以分为海洋特 殊地理条件保护区、海洋生态保护区、海洋公园、 海洋资源保护区等 4 个类型(《海洋特别保护区管理 办法》, www.soa.gov.cn/zwgk/zcgh/sthb/201212/t20 121205_21177.html)。其中海洋特殊地理条件保护区 是在具有重要海洋权益价值、特殊海洋水文动力条 件的海域和海岛建立; 海洋生态保护区在珍稀濒危
物种自然分布区、典型生态系统集中分布区及其他 生态敏感脆弱区或生态修复区建立; 海洋公园在特 殊海洋生态景观、历史文化遗迹、独特地质地貌景 观及其周边海域建立; 海洋资源保护区在重要海洋 生物资源、矿产资源、油气资源及海洋能等资源开 发预留区域、海洋生态产业区及各类海洋资源开发 协调区建立。虽然海洋特别保护区现有大致的分类, 但学术上对于海洋特别保护区的分类体系探索非 常缺乏。

(8)水利风景区。水利风景区分为水库型、湿地 型、自然河湖型、城市河湖型、灌区型和水土保持 型6种类型，见《水利风景区规划编制导则》(SL 471-2010)。其中水库型、湿地型、自然河湖型3种 类型属于本文探讨的自然保护地范畴内。学术上对 于水利风景区的分类体系研究也非常缺乏，多集中 在对水利风景区的水利风景资源研究(汪健等, 2013; 冯仲等, 2016)。

(9)水产种质资源保护区。国家正式的法律法 规、部门规章中暂无分类规定，也暂无关于水产种 质资源保护区类型划分的相关研究。

(10)国家公园体制试点。国家正式的法律法规、 部门规章中暂无分类规定, 在学术研究中, 有学者 建议借鉴自然保护区的分类方法将狭义的国家公 园分为 3 大类 9 个类型(张希武和唐芳林，2014; 唐芳 林和王梦君, 2015)。

以上10类自然保护地中，只有自然保护区、风 景名胜区、海洋特别保护区和水利风景区4类在法 律法规或部门规章中有分类标准; 森林公园、湿地 公园、地质公园和国家公园在学术上有分类体系的 相关探讨; 沙漠公园和水产种质资源保护区的分类 体系在学术研究中还属于空白状态。现有的分类标 准中, 自然保护区和海洋特别保护区按照其保护对 象进行分类; 风景名胜区和水利风景区按照其自然 特征或景观特征分类。相关的自然保护地分类研究 中通常也根据保护对象或自然、景观特征进行分类, 而缺少针对主导功能或管理目标进行分类的标准 或研究。

\section{我国自然保护地的分类构想}

我国当前的自然保护地并无统一规范的分类 体系，本文分别根据IUCN保护区分类系统、保护对 象自然属性和管理目标社会属性, 归纳与提出了三 
种我国自然保护地分类体系的构想。

\section{1 基于IUCN保护区分类系统的自然保护地分类} 体系

在世界保护区数据库(World Database on Protected Area, WDPA)发布的2014年的世界保护区报 告中, 中国大陆被记录的保护区仅有2,160个。其中, 只有雷州珍稀海洋生物国家级自然保护区一处被 认定为严格自然保护区(Ia: Strict Nature Reserve); 国家公园(II: National Park)、自然遗迹(III: Natural Monument or Feature)的记录为 0 ; 生境和物种管理 保护区(IV: Habitat/Species Management Area)有2处, 分别是乌梁素海湿地水禽自治区级自然保护区、安 徽升金湖国家级自然保护区; 陆地和海洋景观保护 区(V: Protected Landscape/Seascape)有1,872处记录, 是数量最多的类型; 自然资源保护区(VI: Protected Area With Sustainable Use of Natural Resources)有22 处记录; 不适用(Not Applicable)的29处, 未报道 (Not Reported) 的 234 处 (Deguignet et al, 2014, https://www.protectedplanet.net/)。该记录未能反映我 国现有自然保护地的现状, 其中, I、IV、VI类记录 不足, II、III类记录缺失, 而最主要的保护地类型一 一自然保护区被归类为 $\mathrm{V}$ 类, 很可能会造成误解 (Wang et al, 2011)。导致这种情况的原因可能有三: 一是我国并没有与国际分类标准相对照或名称相 匹配的分类体系(Wang et al, 2011); 二是由于目前 各类自然保护地的分类方式各异, 不能清楚反映其 管理目标; 三是WDPA与中国自然保护地相关政府 部门或组织之间未能进行深入的交流与探讨, 没有 对数据记录进行补充和修正。

我国现有各自然保护地内部分类系统和分类 依据各不相同, 在保留现有分类结构的基础上, 结 合IUCN保护区分类系统, 作者对我国现有自然保 护地进行重新归类, 分为严格自然保护区、国家公 园、自然遗迹保护区、野生生物保护区、自然景观 保护区和自然资源保护区6类。类别的名称、与 IUCN分类系统的对照、类别关键特征和现有自然 保护地归类见表2。

\section{2 基于保护对象自然属性的自然保护地分类体系}

在同样保留各自然保护地内部分类的基础上, 根据保护对象可将自然保护地分为 5 大类别, 分别 为: 自然生态系统保护区、野生生物保护区、自然 遗迹保护区、自然景观保护区和自然资源保护区。
根据每种类别的自然属性又可以将其细分为不同 的类型，具体如下:

(1)自然生态系统保护区可分为森林、草原与草 甸、荒漠、内陆湿地和水域类、海洋和海岸 5 个类 型, 现有的自然保护地符合该类别的有森林生态系 统类型自然保护区、草原与草甸生态系统类型自然 保护区、荒漠生态系统类型自然保护区、内陆湿地 和水域生态系统类型自然保护区、海洋和海岸生态 系统类型自然保护区和海洋特别保护区中的海洋 特别保护区。

(2)野生生物保护区可分为野生动物和野生植 物保护区两个类型，现有自然保护地符合该类别的 有野生动物类型自然保护区和野生植物类型自然 保护区。

(3)自然遗迹保护区可分为地质遗迹和古生物 遗迹两个类型，现有自然保护地符合该类别的有 地质遗迹类型自然保护区和古生物遗迹类型自然 保护区。

(4)自然景观保护区可分为陆地景观和海洋景 观两个类型，现有自然保护地符合该类别的有风景 名胜区、森林公园、湿地公园、沙漠公园、地质公 园、水利风景区和海洋特别保护区中的海洋公园。

(5)自然资源保护区可分为生物资源和非生物 资源保护区两个类型，现有自然保护地符合该类别 的有水产种质资源保护区、海洋特别保护区中的海 洋特殊地理条件保护区和海洋资源保护区。

\section{3 基于管理目标社会属性的自然保护地分类体系}

为使管理目标更明确, 便于自然保护地的保护 与管理，提出基于管理目标社会属性的自然保护地 分类体系，可将现有自然保护地归纳为 3 个类别, 分别为国家公园、自然保护区和自然风景区。

国家公园的主要目的是保护大面积自然生态 系统的原真性和完整性, 实现自然资源科学保护和 合理利用, 解决现有自然保护地交叉重叠、多头管 理的碎片化问题。该类别仅包括国家公园体制试点 中将被正式批准的国家公园。

自然保护区的主要目的是对有重要生态意义 或特殊意义的自然生态系统、野生生物、自然遗迹 和自然资源进行保护，类别包括现有的自然保护 区、水产种质资源保护区、海洋特别保护区中的海 洋生态保护区、海洋特殊地理条件保护区和海洋资 源保护区。 
表2 基于IUCN保护区分类系统提出的中国自然保护地分类体系

Table 2 The natural protected area classification system based on IUCN protected area categories

\begin{tabular}{lll}
$\begin{array}{l}\text { IUCN保护区分类 } \\
\text { 对照类别 }\end{array}$ & 现有自然保护地归类 \\
IUCN protected & Extrol category & \\
$\begin{array}{l}\text { area classification } \\
\text { system. }\end{array}$ & \\
\hline
\end{tabular}

\begin{tabular}{ll}
\hline I: Strict Nature & 严格自然保护区 Strict Nature Reserve \\
Reserve & 关键特征: 具有极高原真性和完整性的自然生态系统以 \\
& 及极高生物多样性价值; 区域内严格限制人为活动。 \\
& Critical features: Natural ecosystems with a high level of \\
& authenticity and integrity, high biodiversity value, and strict \\
& limits on human activities. \\
II: National Park & 国家公园 National Park \\
& 关键特征: 具有国家代表性的大面积自然生态系统; 可 \\
& 实现自然资源科学保护和合理利用的特定陆地或海洋区 \\
& 域。 \\
& Critical features: Specific land or marine areas which have \\
& large-scale natural ecosystems with national representation; \\
& and natural resources that can be scientifically protected \\
& and rationally used.
\end{tabular}

$\begin{array}{ll}\text { III: Natural } & \text { 自然遗迹保护区 Natural Relic Reserve } \\ \text { Monument } & \text { 关键特征: 地质遗迹或古生物遗迹 } \\ \text { or Feature } & \text { Critical features: Geological relics or paleontological relics }\end{array}$

自然生态系统类型的自然保护区(包括森林、草原与草甸、荒漠、 内陆湿地和水域、海洋和海岸带生态系统5个类型); 海洋特别保 护区中的海洋生态保护区类型

Nature reserve protecting natural ecosystem (including five ecosystem types: forest, grass land and meadow, desert, inland wetlands and waters, marine and coastal zone); Marine ecological reserve in marine special reserve.

国家公园体制试点中将被正式批准的国家公园

National park pilots that will be approved as a formal national park 实现自然资源科学保护和合理利用的特定陆地或海洋区 域。

Critical features: Specific land or marine areas which have large-scale natural ecosystems with national representation; and natural resources that can be scientifically protected 自然遗迹保护区 Natural Relic Reserve

Critical features: Geological relics or paleontological relics

IV: Habitat/Species Management Area 野生生物保护区 Wildlife Reserve 关键特征: 重点保护野生动植物的集中分布地及其生境 Critical features: The concentration area of key protected wild plants, animals and their habitats

V: Protected Landscape/ Seascape

VI: Protected Area with Sustainable Use of Natural Resources
自然遗迹类自然保护区(包括地质遗迹类型自然保护区和古生 物遗迹类型自然保护区); 地质公园

Nature reserve protecting nature relics (including geological relics and paleontological relics); Geopark

野生生物类自然保护区(包括野生动物类型的自然保护区; 野生 植物类型的自然保护区)

Wildlife nature reserve protecting wildlife (including wild animals and wild plants)

风景名胜区(仅包括自然景观类); 森林公园; 湿地公园; 水利风 景区(仅包括水库型、湿地型、自然河湖型); 海洋公园; 沙漠公 园

Scenic and history area (including natural landscape); Forest park; Wetland park; Water park (Including reservoirs, wetlands and natural lakes); Ocean park; Desert park

海洋特别保护区中的海洋资源保护区; 海洋特别保护区中的海 洋特殊地理条件保护区; 水产种质资源保护区

Marine resources reserve in marine special reserve; Special geographic marine reserve in marine special reserve; Fishery genetic resources reserve
自然风景区的主要目的是保护自然景观并为 公众提供观光游览和自然体验的功能，包括以自 然景物为主的风景名胜区(仅包括自然景观类)、森 林公园、湿地公园、沙漠公园、海洋公园、地质公 园和水利风景区(仅包括水库型、湿地型、自然河 湖型)。

\section{建议与讨论}

(1)明确自然保护地的定义。目前国内各类自然 保护实体并无法律法规上的统一名称和定义, 容易
引起混淆，如“自然保护区”、“自然保护地”、“自然 遗产地”、“保护区”等。“保护区”国际上的表述为 “protected area”, 其中“area”一词解释了其定义中 “明晰的地理空间”的内涵。通过表2可以看出, 我国 各类自然保护实体也都具有区域范围的空间属性, 因此将“protected area”翻译为“保护区”更为合适; 而“保护地”中的“地”一词对应英文中的“site”, 含义 为“地点、位置、场所等”，如世界自然遗产地(World Natural Heritage Site)、美国国家公园体系中的国家 历史遗迹地(National Historic Site)。为了避免所用名 
词不同引起的混淆, 区分开以自然特征为主的保护 区与人文特征为主的保护区，防止“保护区(protected area)" 与狭义自然保护区(nature reserve)在称 呼上的近似造成混淆，因此本文建议将各类以自然 特征为主的自然保护实体统一称之为广义自然保 护区(generalized nature reserve)。

(2)建立一套有利于国际交流的分类体系。为了 有利于自然保护地领域的国际交流, 建议建立一套 能与国际现行保护区分类标准相对照的分类体系。 本文根据IUCN的分类依据归纳出基于IUCN保护区 分类系统的中国自然保护地分类体系, 分别有严格 自然保护区、国家公园、自然遗迹保护区、野生生 物保护区、自然景观保护区和自然资源保护区6类， 并将与之对应的现有自然保护地类型进行了归类。

(3)根据统一的分类依据, 构建适用于我国的 自然保护地分类体系。我国当前的自然保护地并无 统一规范的分类体系, 一是现有自然保护地类型暂 无明确规定, 本文统计为 10 类; 二是各自然保护地 的内部分类各成体系, 且缺少分类标准和统一的分 类依据。因此，建议整合现有自然保护地及其内部 分类，根据统一的分类依据构建适用于我国的自然 保护地分类体系。本文分别提出了基于保护对象自 然属性和基于管理目标社会属性的中国自然保护 地分类体系。前者根据保护对象将自然保护地分为 自然生态系统保护区、野生生物保护区、自然遗迹 保护区、自然景观保护区和自然资源保护区 5 个类 别, 根据每种类型的自然属性又可以将其细分为森 林、草原与草甸、荒漠等13个类型; 后者根据管理 目标将现有自然保护地分为国家公园、自然保护区 和自然风景区 3 个类别。

(4)关注自然保护地边界不清、地理空间重叠、 主导功能模糊等问题。我国现有自然保护地中仍然 有范围和边界不清的情况, 并且存在较多自然保护 地空间重叠和一处保护地挂多块牌子的现象, 导致 多头管理以及自然保护地的主导功能模糊等问题。因 此, 在构建自然保护地体系过程中, 应当关注科学规 划自然保护地, 研究交叉重叠现状及整合方法, 确定 自然保护地的主导功能及科学划定功能区等问题。

\section{参考文献}

Chen G, Xia ZK, Yu H (2001) Concept, types, and functions of forest park. Forest Resources Management, (3), 41-45. (in
Chinese with English abstract) [陈戈, 夏正楷, 俞晖 (2001) 森林公园的概念、类型与功能. 林业资源管理, (3), 41-45.]

Deguignet M, Juffe-Bignoli D, Harrison J, Macsharry B, Burgess N, Kingston N (2014) 2014 United Nations List of Protected Areas. UNEP-WCMC, Cambridge, UK.

Dudley N (2008) Guidelines for Applying Protected Area Management Categories. IUCN, Gland, Switzerland.

Feng Z, Xie XC, Zhang L, Wang SH (2016) The classification survey and evaluation method for water conservancy landscape resources. Water Resources Development Research, 16(3), 47-53. (in Chinese) [冯冲, 谢祥财, 张蕾, 汪升华 (2016) 水利风景资源分类调查与评价方法. 水利发展研 究, 16(3), 47-53.]

General Administration of Quality Supervision, Inspection and Quarantine of the People's Republic of China (1993) Principle for Categories and Grades of Nature Reserves. Standards Press of China, Beijing. (in Chinese) [国家技术监督局, 国 家环境保护局 (1993) 自然保护区类型与级别划分原则. GB/T 14529-1993. 中国标准出版社, 北京.]

General Administration of Quality Supervision, Inspection and Quarantine of the People's Republic of China, Standardization Administration of the People's Republic of China (2015) Nature Reserve Terminology. GB/T 31759-2015. Standard Press of China, Beijing. (in Chinese) [中华人民共 和国国家质量监督检验检疫总局，中国国家标准化管理 委员会 (2015) 自然保护区名词术语. GB/T 31759-2015. 中国标准出版社, 北京.]

Hou LS (2005) The development of national geopark and its developmental phases. Contemporary Economic Management, 27(1), 63-65. (in Chinese with English abstract) [后立 胜 (2005) 国家地质公园的发展及其阶段性. 当代经济 管理, 27(1), 63-65.]

Jia JZ (2012) Development and planning characteristics of scenic areas of China. Chinese Landscape Architecture, (11), 11-15. (in Chinese with English abstract) [贾建中 (2012) 我国风景名胜区发展和规划特性. 中国园林, (11), 11-15.]

Jiang MK, Wang Z, Zhu GQ, Tao SM, Zhou HL (2004) Chinese nature reserve classification standard based on IUCN Protected Area Categories. Rural Eco-Environment, 20(2), 1-6. (in Chinese with English abstract) [蒋明康, 王智, 朱 广庆, 陶思明, 周海丽 (2004) 基于IUCN保护区分类系 统的中国自然保护区分类标准研究. 生态与农村环境学 报, 20(2), 1-6.]

Li BQ, Wu CC, Wu ZW (2009) The development roadmap analysis on China's forest parks. Acta Ecologica Sinica, 29, 2749-2756. (in Chinese with English abstract) [李柏青, 吴楚材, 吴章文 (2009) 中国森林公园的发展方向. 生态 学报, 29, 2749-2756.]

Li XL, Han F (2015) Elucidations on categorization of China's scenic and historic interest areas and its dilemmas. Urban Development Studies, 22(4), 74-79. (in Chinese with Eng- 
lish abstract) [李晓黎, 韩锋 (2015) 我国风景名胜区分类 现状及其症结剖析. 城市发展研究, 22(4), 74-79.]

Liu DP, He ZP, Zhang Y, Yue YJ (2010) The development of special marine reserves and policy recommendations. China Population, Resources and Environment, 20(S1), 157-160. (in Chinese) [刘东朴, 贺志鹏, 张英, 岳英洁 (2010) 海 洋特别保护区的发展历程与政策建议. 中国人口、资源与 环境, 20(S1), 157-160.]

Ministry of Housing and Urban-Rural Construction of the People's Republic of China (2008) Standard for Scenic and Historic Areas Classification. CJJ/T 121-2008. China Architecture \& Building Press, Beijing. (in Chinese) [中华人 民共和国住房和城乡建设部 (2008) 风景名胜区分类标 准. CJJ/T 121-2008. 中国建筑工业出版社, 北京.]

Tang FL, Wang MJ (2015) Discussion on the classification of national park. Forestry Construction, (5), 25-31. (in Chinese with English abstract) [唐芳林, 王梦君 (2015) 国家公园 类型划分的探讨. 林业建设, (5), 25-31.]

Wang J, Lu YQ, Qian XC (2013) Research on the classification and evaluation of water conservancy tourism resource in Hangzhou, 13(8), 80-84. (in Chinese) [汪健, 陆一奇, 钱学 诚 (2013) 杭州市水利旅游资源分类与评价研究. 水利 发展研究, 13(8), 80-84.]

Wang L, Chen A, Gao Z (2011) An exploration into a diversified world of National Park Systems: China's prospects within a global context. Journal of Geographical Sciences, 21, 882-896.

Wang XP, Cui GF (2003) Construction and Management of Nature Reserves. Chemical Industry Press, Beijing. (in Chinese) [王献溥, 崔国发 (2003) 自然保护区建设与管理. 化学工业出版社, 北京.]

Wu SM (2003) A list and classification of China's national geological parks. Science \& Technology Review, 21(5), 63-64. (in Chinese) [吴胜明 (2003) 中国国家地质公园的 名录和分类. 科技导报, 21(5), 63-64.]

Yang R (2016) Study on National Parks and Protected Areas. China Architecture and Building Press, Beijing. (in Chinese) [杨锐 (2016) 国家公园与自然保护地研究. 中国建筑工 业出版社, 北京.]

Yang YF (2014) Analysis of national wetland park construction and development. Forest Resources Management, (4), 39-45. (in Chinese with English abstract) [杨永峰 (2014) 我国国家湿地公园建设与发展问题浅析. 林业资源管理, (4), 39-45.]

Yu FL, Huang ZF, Shang ZY (2012) Value connotation and development course and running status of water park. Economic Geography, 32(12), 169-175. (in Chinese with English abstract) [余凤龙, 黄震方, 尚正永 (2012) 水利风景 区的价值内涵、发展历程与运行现状的思考. 经济地理, 32(12), 169-175.]

Yunnan Provincial Bureau of Quality and Technical Supervision (2009) National Park-Basic Criteria. DB53/T 298-2009. (in Chinese) [云南省质量技术监督局 (2009) 国家公园基 本条件. DB53/T 298-2009.]

Zhang XW, Tang FL (2014) Chinese National Park Exploration and Practice. China Forestry Publishing House, Beijing. (in Chinese) [张希武, 唐芳林 (2014) 中国国家公园的探索 与实践. 中国林业出版社, 北京.]

Zhao SY, Shi FF (2006) The Concept of Wetland and Design of Wetland Park. Southeast University Press, Nanjing. (in Chinese) [赵思毅, 侍菲菲 (2006) 湿地概念与湿地公园 设计. 东南大学出版社, 南京.]

(责任编委: 李俊生 责任编辑: 时意专) 